\title{
Isoptericola hypogeus sp. nov., isolated from the Roman catacomb of Domitilla
}

Correspondence

Ingrid Groth

Ingrid.Groth@hki-jena.de

\author{
Ingrid Groth, ${ }^{1}$ Peter Schumann, ${ }^{2}$ Barbara Schütze, ${ }^{1}$ Juan M. Gonzalez, ${ }^{3}$ \\ Leonila Laiz, ${ }^{3}$ Cesareo Saiz-Jimenez ${ }^{3}$ and Erko Stackebrandt ${ }^{2}$ \\ ${ }^{1}$ Leibniz-Institut für Naturstoff-Forschung und Infektionsbiologie e. V., Hans-Knöll-Institut, \\ Beutenbergstrasse 11a, 07745 Jena, Germany \\ ${ }^{2}$ DSMZ-Deutsche Sammlung von Mikroorganismen und Zellkulturen GmbH, Mascheroder Weg \\ 1b, 38124 Braunschweig, Germany \\ ${ }^{3}$ Instituto de Recursos Naturales y Agrobiologia, CSIC, Apartado 1052, 41080 Sevilla, Spain
}

In order to clarify the taxonomic position of an actinobacterium from the Roman catacomb of Domitilla, a combination of phenotypic characterization, phylogenetic analysis based on the $16 \mathrm{~S}$ rRNA gene sequence and DNA-DNA relatedness studies was used. The results from the polyphasic taxonomic study of this organism showed that strain $\mathrm{HKI} 0342^{\top}$ (=DSM $16849^{\top}=$ NCIMB $14033^{\top}$ ) should be considered as the type strain of a novel species of the genus Isoptericola, for which the name Isoptericola hypogeus sp. nov. is proposed.
The genus Isoptericola has been proposed by Stackebrandt et al. (2004) for the misclassified species Cellulosimicrobium variabile Bakalidou et al. 2002 and is currently based on this single species. The type strain, which is the only representative of Isoptericola variabilis at the time of writing, was isolated from the hindgut of the Australian termite Mastotermes darwiniensis (Frogatt). I. variabilis is phylogenetically closely related to members of the genera $X y l$ animonas (Rivas et al., 2003), Xylanibacterium (Rivas et al., 2004) and Xylanimicrobium (Stackebrandt \& Schumann, 2004). The latter genus has been recently established to harbour the misclassified species Promicromonospora pachnodae (Cazemier et al., 2003, 2004), the type strain of which was isolated from the hindgut of larvae of the scarab beetle Pachnoda marginata. Together, these four genera constitute a phylogenetically distinct cluster within the suborder Micrococcineae, and have cellulolytic and xylanolytic activities in common.

Strain HKI $0342^{\mathrm{T}}$ was isolated from a sample of tufa collected in the burial chamber of the first arcosolium behind the entrance to the Roman catacomb of Domitilla (Rome, Italy); PY-BHI agar (Yokota et al., 1993) and a standard dilution-plate procedure were used. General laboratory cultivation, morphological studies, determination of optimal growth parameters (temperature, $\mathrm{pH}$,

Published online ahead of print on 15 April 2005 as DOI 10.1099/ ijs.0.63632-0.

The GenBank/EMBL/DDBJ accession number for the 16S rRNA gene sequence of strain HKI $0342^{\top}$ is AJ854061.

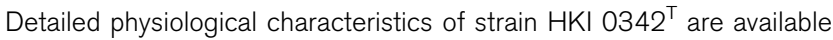
as supplementary material in IJSEM Online. oxygen requirements) and antibiotic-susceptibility tests were performed, using solid or liquid organic medium 79 (Prauser \& Falta, 1968) and an incubation temperature of $28{ }^{\circ} \mathrm{C}$. Cell morphology and cell dimensions were examined by using phase-contrast microscopy with a Zeiss Axioscope 2 microscope equipped with image-analysing software (Axio Vision 2.05). The colony morphology of 2-10-dayold cultures was studied using a stereo microscope (Olympus). Standard physiological tests were carried out according to the methods described by Cowan \& Steel (1965), Gordon et al. (1974), Lanyi (1987) and Smibert \& Krieg (1994). Acid production from carbon sources and enzyme activities were studied using the API $50 \mathrm{CHB} / \mathrm{E}$ kit (incubation times of up to 7 days) and API ZYM galleries (bioMérieux). Additionally, the utilization of carbon sources was tested using Biolog GP2 MicroPlates and MicroLog computer software (Biolog Identification System). Xylanolytic activity was determined on medium II, described by Cazemier et al. (2003), and incubation times of up to 28 days. Susceptibility to antibiotics was examined by placing antibiotic discs (Difco) on agar plates that were seeded with suspensions of the test strains grown in a soft agar layer for $24 \mathrm{~h}$ at $28^{\circ} \mathrm{C}$. Oxygen requirements were studied with the GENbag microaer and GENbag anaer incubation systems (bioMérieux). The $\mathrm{pH}$ range for growth was established by using liquid medium adjusted to $\mathrm{pH}$ values between 4 and 11 with either $1 \mathrm{M} \mathrm{HCl}$ or $20 \%$ (w/v) $\mathrm{Na}_{2} \mathrm{CO}_{3}$ solution and incubated at $28{ }^{\circ} \mathrm{C}$ for up to 10 days. The reference strains used for comparisons in physiological tests and DNA-DNA pairing studies were I. variabilis DSM $10177^{\mathrm{T}}$, Xylanimicrobium pachnodae DSM $12657^{\mathrm{T}}$, Xylanimonas cellulosilytica DSM $15894^{\mathrm{T}}$ and Myceligenerans xiligouense DSM $15700^{\mathrm{T}}$. Biomass for chemotaxonomic 
Table 1. Differential physiological characteristics of strain $\mathrm{HKI} 0342^{\top}$ and $I$. variabilis DSM $10177^{\top}$

\begin{tabular}{|c|c|c|}
\hline Characteristic & $\begin{array}{c}\text { HKI } \\
0342^{\mathrm{T}}\end{array}$ & $\begin{array}{c}\text { DSM } \\
10177^{\mathrm{T}}\end{array}$ \\
\hline \multicolumn{3}{|l|}{ Decomposition of: } \\
\hline Urea & - & + \\
\hline \multicolumn{3}{|l|}{ Utilization of: } \\
\hline Aconitate & - & + \\
\hline Citrate & - & + \\
\hline Malate & $+^{*}$ & - \\
\hline \multicolumn{3}{|l|}{ Growth characteristics } \\
\hline GENbag anaer & - & $+\dagger$ \\
\hline Growth at $10^{\circ} \mathrm{C}$ & + & - \\
\hline Growth at $42{ }^{\circ} \mathrm{C}$ & - & + \\
\hline Growth in the presence of $10 \cdot 0 \% \mathrm{NaCl}$ & - & + \\
\hline Susceptibility to streptomycin $(10 \mu \mathrm{g})$ & + & - \\
\hline \multicolumn{3}{|l|}{ Enzyme assay (API ZYM) } \\
\hline$\alpha$-Galactosidase & - & + \\
\hline \multicolumn{3}{|l|}{ API $50 \mathrm{CH} / \mathrm{BE}$} \\
\hline Methyl $\beta$-xyloside & - & + \\
\hline Methyl $\alpha$-D-glucoside & - & + \\
\hline Melibiose & - & + \\
\hline Melezitose & - & + \\
\hline D-Raffinose & - & + \\
\hline \multicolumn{3}{|l|}{ Biolog GP2 MicroPlate ( $24 \mathrm{~h}$ incubation) } \\
\hline Glycogen & - & + \\
\hline$N$-Acetyl-D-mannosamine & - & + \\
\hline Amygdalin & - & + \\
\hline L-Fucose & - & + \\
\hline Gentiobiose & - & + \\
\hline D-Gluconic acid & - & + \\
\hline$\alpha$-D-Lactose & - & + \\
\hline Lactulose & - & + \\
\hline D-Mannitol & - & + \\
\hline D-Melezitose & - & + \\
\hline D-Melibiose & - & + \\
\hline Methyl $\alpha$-D-galactoside & - & + \\
\hline Methyl $\beta$-D-galactoside & - & + \\
\hline Methyl $\alpha$-D-glucoside & - & + \\
\hline Methyl $\beta$-D-glucoside & - & + \\
\hline Methyl $\alpha$-D-mannoside & - & + \\
\hline Palatinose & - & + \\
\hline D-Raffinose & - & + \\
\hline L-Rhamnose & - & + \\
\hline D-Sorbitol & - & + \\
\hline Stachyose & - & + \\
\hline Sucrose & - & + \\
\hline D-Trehalose & - & + \\
\hline Turanose & - & + \\
\hline Acetic acid & - & + \\
\hline$\gamma$-Hydroxybutyric acid & + & - \\
\hline L-Lactic acid & - & + \\
\hline Monomethyl succinate & - & + \\
\hline Propionic acid & - & + \\
\hline L-Glutamic acid & - & + \\
\hline L-Serine & - & + \\
\hline
\end{tabular}

Table 1. cont.

\begin{tabular}{|c|c|c|}
\hline Characteristic & $\begin{array}{c}\text { HKI } \\
0342^{T}\end{array}$ & $\begin{array}{c}\text { DSM } \\
10177^{\mathrm{T}}\end{array}$ \\
\hline 2'-Deoxyadenosine & - & + \\
\hline Inosine & - & + \\
\hline Thymidine & - & + \\
\hline Adenosine $5^{\prime}$-monophosphate & - & + \\
\hline
\end{tabular}

${ }^{\star}$ Delayed reaction.

$\dagger$ Data from Cui et al. (2004).

and molecular systematic studies was prepared by growing the strain in shake flasks containing liquid organic medium 79 or Bacto tryptic soy broth (Sigma-Aldrich) for $24-48 \mathrm{~h}$. Stock cultures of strain HKI $0342^{\mathrm{T}}$ in liquid organic medium 79 supplemented with $5 \%$ DMSO were maintained in either the vapour phase of liquid nitrogen or at $-80^{\circ} \mathrm{C}$ by adding a 1:1 mixture of glycerol and a medium that consisted of $\mathrm{K}_{2} \mathrm{HPO}_{4}(1 \cdot 26 \%), \mathrm{KH}_{2} \mathrm{PO}_{4}(0 \cdot 36 \%), \mathrm{MgSO}_{4}(0 \cdot 01 \%)$, sodium citrate $(0.09 \%),\left(\mathrm{NH}_{4}\right)_{2} \mathrm{SO}_{4}(0 \cdot 18 \%)$ and glycerol $(8 \cdot 8 \%)$.

On medium 79, strain HKI $0342^{\mathrm{T}}$ formed wrinkled, circular, smooth, pale-yellow colonies about $1-4 \mathrm{~mm}$ in diameter. In young cultures $(8-24 \mathrm{~h})$, a well-developed primary mycelium (width $0 \cdot 6-0 \cdot 7 \mu \mathrm{m}$ ) was observed which fragmented, in the stationary growth phase $(48-72 \mathrm{~h})$, into irregular, non-motile, short rods and cocci (diameter $0 \cdot 8-1 \cdot 0 \mu \mathrm{m}$ ). In contrast to stationary-phase cultures of $I$. variabilis, both cell types were arranged mainly as short flexible chains or as clusters. Furthermore, strain HKI $0342^{\mathrm{T}}$ and I. variabilis DSM $10177^{\mathrm{T}}$ exhibited different growth characteristics (Table 1). The catacomb isolate was an aerobic to microaerophilic organism and did not grow in an anaerobic atmosphere, unlike I. variabilis DSM $10177^{\mathrm{T}}$, which is a facultatively anaerobic organism (Bakalidou et al., 2002). I. variabilis grew at temperatures up to $45^{\circ} \mathrm{C}$, but not at $10^{\circ} \mathrm{C}$, while strain HKI $0342^{\mathrm{T}}$ did not grow above $40^{\circ} \mathrm{C}$, but grew well at $10^{\circ} \mathrm{C}$. Both strains had in common the ability to hydrolyse xylan. However, they could be readily distinguished from one another by means of a broad spectrum of physiological properties. Clearly differential characteristics of the two strains under study are listed in Table 1. Full detailed results (classical physiological tests, API kits and Biolog test) are provided as supplementary tables in IJSEM Online.

For sequence analysis of the $16 \mathrm{~S}$ rRNA gene, bacterial DNA was extracted according to the method described by Marmur (1961). The $16 \mathrm{~S}$ rRNA gene was amplified by a PCR using the conserved primers 27F (5'-AGAGTTTGATCCTGGCTCAG-3') and 1522R (5'-AAGGAGGTGATCCAGCCGCA- $\left.3^{\prime}\right)$. PCR thermal conditions were as follows: $95^{\circ} \mathrm{C}$ for $1 \mathrm{~min} ; 35$ cycles of $95^{\circ} \mathrm{C}$ for $15 \mathrm{~s}, 55^{\circ} \mathrm{C}$ for $15 \mathrm{~s}$ and $72^{\circ} \mathrm{C}$ for $2 \mathrm{~min}$; and a final extension cycle at $72^{\circ} \mathrm{C}$ for $10 \mathrm{~min}$. Forward and reverse strands of the amplified DNA fragment 
were sequenced in an ABI 3700 sequencer (Applied Biosystems). The 16S rRNA gene sequences of the strains studied were aligned manually with nucleotide sequences obtained from the GenBank and EMBL databases. The algorithm of Jukes \& Cantor (1969) was applied in order to transform sequence dissimilarities into evolutionary distances. Phylogenetic dendrograms were reconstructed by using the method of De Soete (1983) and the neighbourjoining method (Felsenstein, 1993).

The binary 16S rRNA gene sequence similarity values between strain HKI $0342^{\mathrm{T}}$ and its nearest phylogenetic neighbours range between $95 \cdot 0$ and $98 \cdot 8 \%$. A dendrogram of relationships based on the Jukes \& Cantor (1969) corrections of similarity values (Fig. 1) shows strain HKI $0342^{\mathrm{T}}$ as branching next to I. variabilis DSM $10177^{\mathrm{T}}$ $(98 \cdot 8 \%)$, whereas members of Xylanimonas and relatives, Cellulosimicrobium and Promicromonospora are less closely related. To determine the genomic relatedness between strains DSM $10177^{\mathrm{T}}$ and HKI $0342^{\mathrm{T}}$, DNA-DNA similarity studies were performed.

For DNA-DNA relatedness studies, DNA was isolated using a French pressure cell (Thermo Spectronic) and was purified by chromatography on hydroxyapatite as described by Cashion et al. (1977). DNA-DNA hybridization was carried out as described by De Ley et al. (1970) under consideration of the modifications described by Huß et al. (1983), using a model Cary 100 Bio UV/VIS-spectrophotometer equipped with a Peltier-thermostatted $6 \times 6$ multicell changer and a temperature controller with an in-situ temperature probe (Varian). The DNA G+C content was determined as recommended by Mesbah et al. (1989).

Strains HKI $0342^{\mathrm{T}}$ and DSM $10177^{\mathrm{T}}$ shared a mean DNADNA relatedness value of $31.7 \%$ (individual values of 33.4 and $30.0 \%$ ), a value which clearly indicates that the two strains belong to distinct genomic species.

The following chemotaxonomic characteristics were determined: the structure of the peptidoglycan, as described by Schleifer \& Kandler (1972), Schleifer (1985), MacKenzie
(1987), Groth et al. (1996) and Frank et al. (1980); the acyl type of the muramic acid, as described by Uchida et al. (1999); the whole-cell sugars present, as described by Becker et al. (1965) and Saddler et al. (1991); the menaquinones present, as described by Groth et al. (1996); the polar lipids present, as described by Minnikin et al. (1979) and Collins \& Jones (1980); the mycolic acids present, as described by Minnikin et al. (1975); and the fatty acid profile (MIDI system; Agilent).

The chemotaxonomic characteristics of strain HKI $0342^{\mathrm{T}}$ were most similar to those of I. variabilis and supported the affiliation of this organism to the genus Isoptericola. The peptidoglycan contained $\mathrm{N}$-acetylated muramic acid and corresponded to type A4 $\alpha$, L-Lys-D-Glu (A11.33 according to http://www.dsmz.de/species/murein.htm). Strain HKI $0342^{\mathrm{T}}$ differs from I. variabilis in having D-Glu instead of DAsp as the interpeptide bridge. Glucose, rhamnose, galactose and a minor amount of mannose were found in whole-cell hydrolysates. Strain HKI $0342^{\mathrm{T}}$ was characterized by the presence of menaquinones with nine isoprene units, which differs from I. variabilis in that the major components were MK-9 $\left(\mathrm{H}_{2}\right)$ and MK-9 (peak areas 42:29, respectively) instead of MK-9 $\left(\mathrm{H}_{4}\right)$ (peak area 10). The phospholipids were diphosphatidylglycerol, phosphatidylglycerol, phosphatidylinositol mannoside, phosphatidylinositol, two unknown phospholipids and an unknown glycolipid. In addition to the polar lipid components reported by Stackebrandt et al. (2004) for I. variabilis, phosphatidylinositol mannoside was also detected in strain DSM $10177^{\mathrm{T}}$ in this study. The fatty acid profile consisted of anteiso$\mathrm{C}_{15: 0} \quad(44 \cdot 0 \mathrm{~mol} \%)$, iso- $\mathrm{C}_{16: 0}(22.6 \mathrm{~mol} \%)$, iso- $\mathrm{C}_{15: 0}$ $(18 \cdot 1 \mathrm{~mol} \%)$, iso- $\mathrm{C}_{14: 0}(8 \cdot 4 \mathrm{~mol} \%)$ and anteiso- $\mathrm{C}_{17: 0}$ (3.1 mol\%). Mycolic acids were not detected.

It is evident from Fig. 1 that strain HKI $0342^{\mathrm{T}}$ is most closely related to the type strain of $I$. variabilis. The low level of DNA-DNA relatedness (about $30 \%$ ) between the two strains, together with the numerous differences in chemotaxonomic, morphological and a broad range of physiological characteristics (Table 1), clearly indicates that strain HKI $0342^{\mathrm{T}}$ represents a novel species of the genus

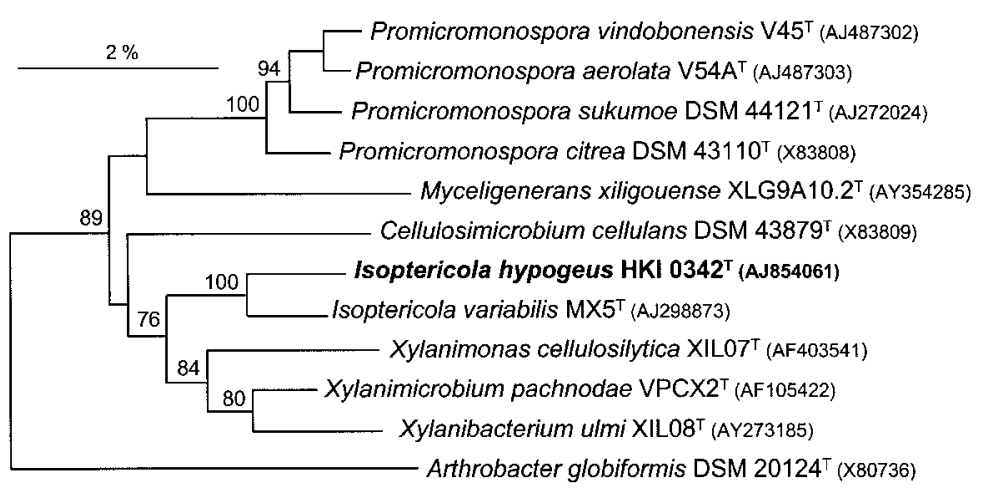

Fig. 1. Phylogenetic relatedness among members of the genera Isoptericola, Xylanimonas, Xylanimicrobium, Xylanibacterium, Cellulosimicrobium, Myceligenerans and Promicromonospora, based on 16S rRNA gene sequence comparison. Arthrobacter globiformis DSM 20124 ${ }^{\top}$ (X80736) was used as the outgroup. The dendrogram was generated by neighbour-joining analysis (Felsenstein, 1993). Numbers within the dendrogram indicate the percentages of occurrence of the branching order in 100 bootstrapped trees (only values of $50 \%$ and above are shown). Bar, 2 substitutions per $100 \mathrm{nt}$. 
Isoptericola, for which the name Isoptericola hypogeus is proposed.

\section{Description of Isoptericola hypogeus sp. nov.}

Isoptericola hypogeus (hy.po.ge'us. L. masc. adj. hypogeus underground, referring to the site of isolation).

Gram-positive, aerobic to microaerophilic actinomycete with a well-developed primary mycelium (diameter of hyphae $0 \cdot 6-0 \cdot 7 \mu \mathrm{m})$ that undergoes fragmentation into short, irregular, non-motile rods and cocci (diameter $0 \cdot 8$ $1.0 \mu \mathrm{m})$ in the stationary growth phase. Aerial mycelium is absent. Colonies on organic medium 79 are wrinkled, circular, smooth and pale yellow (diameter about 1-4 mm). Growth occurs between 10 and $40{ }^{\circ} \mathrm{C}$ (optimal growth at $28^{\circ} \mathrm{C}$ ) and at $\mathrm{pH}$ values in the range of $6-9 . \mathrm{NaCl}$ in the culture medium is tolerated at concentrations up to $10 \%$. Physiological characteristics relating to the utilization of carbohydrates, enzyme activities and susceptibility to antibiotics are listed in Table 1 and in the supplementary data available in IJSEM Online. The peptidoglycan type is A4 $\alpha$, L-Lys-D-Glu. The whole-cell sugars comprise glucose, rhamnose, galactose and a minor amount of mannose. The acyl type is acetyl. The menaquinones comprise MK9( $\left.\mathrm{H}_{2}\right)$, MK-9 and MK-9 $\left(\mathrm{H}_{4}\right)$ (peak areas $42: 29: 10$ ) and the major fatty acids are anteiso- $\mathrm{C}_{15: 0}(44 \cdot 0 \mathrm{~mol} \%)$, iso- $\mathrm{C}_{16: 0}(22 \cdot 6 \mathrm{~mol} \%)$, iso- $\mathrm{C}_{15: 0}(18 \cdot 1 \mathrm{~mol} \%)$, iso- $\mathrm{C}_{14: 0}$ $(8 \cdot 4 \mathrm{~mol} \%)$ and anteiso- $\mathrm{C}_{17: 0}(3 \cdot 1 \mathrm{~mol} \%)$. The phospholipids comprise diphosphatidylglycerol, phosphatidylglycerol, phosphatidylinositol mannoside, phosphatidylinositol, two unknown phospholipids and an unknown glycolipid. Mycolic acids are absent. The $\mathrm{G}+\mathrm{C}$ content of the DNA of the type strain is $73 \cdot 8 \mathrm{~mol} \%$.

The type strain, HKI $0342^{\mathrm{T}}\left(=\mathrm{DSM} 16849^{\mathrm{T}}=\mathrm{NCIMB}\right.$ $14033^{\mathrm{T}}$ ), was isolated from a tufa sample from a burial chamber in the catacomb of Domitilla, Rome, Italy.

\section{Acknowledgements}

This work was supported by the EC Programme 'Energy, Environment and Sustainable Development', within the framework of the CATS Project, contract EVK4-CT-2000-00028). We are grateful to Christiane Weigel, Carmen Schult and Renate Schön for excellent technical assistance.

\section{References}

Bakalidou, A., Kämpfer, P., Berchtold, M., Kuhnigk, T., Wenzel, M. \& König, H. (2002). Cellulosimicrobium variabile sp. nov., a cellulolytic bacterium from the hindgut of the termite Mastotermes darwiniensis. Int J Syst Evol Microbiol 52, 1185-1192.

Becker, B., Lechevalier, M. P. \& Lechevalier, H. A. (1965). Chemical composition of cell-wall preparations from strains of various formgenera of aerobic actinomycetes. Appl Microbiol 13, 236-243.

Cashion, P., Holder-Franklin, M. A., McCully, J. \& Franklin, M. (1977). A rapid method for the base ratio determination of bacterial DNA. Anal Biochem 81, 461-466.
Cazemier, A. E., Verdoes, J. C., Reubsaet, F. A. G., Hackstein, J. H. P., van der Drift, C. \& Op den Camp, H. J. M. (2003). Promicromonospora pachnodae sp. nov., a member of the (hemi)cellulolytic hindgut flora of larvae of the scarab beetle Pachnoda marginata. Antonie van Leeuwenhoek 83, 135-148.

Cazemier, A. E., Verdoes, J. C., Reubsaet, F. A. G., Hackstein, J. H. P., van der Drift, C. \& Op den Camp, H. J. M. (2004). Promicromonospora pachnodae sp. nov. In Validation of the Publication of New Names and New Combinations Previously Effectively Published Outside the IJSEM, List No 95. Int J Syst Evol Microbiol 54, 1-2.

Collins, M. D. \& Jones, D. (1980). Lipids in the classification and identification of coryneform bacteria containing peptidoglycans based on 2,4-diaminobutyric acid. J Appl Bacteriol 48, 459-470.

Cowan, S. T. \& Steel, K. J. (1965). Manual for the Identification of Medical Bacteria. Cambridge: Cambridge University Press.

Cui, X., Schumann, P., Stackebrandt, E., Kroppenstedt, R. M., Pukall, R., Xu, L., Rohde, M. \& Jiang, C. (2004). Myceligenerans xiligouense gen. nov., sp. nov., a novel hyphae-forming member of the family Promicromonosporaceae. Int J Syst Evol Microbiol 54, 1287-1293.

De Ley, J., Cattoir, H. \& Reynaerts, A. (1970). The quantitative measurement of DNA hybridization from renaturation rates. Eur J Biochem 12, 133-142.

De Soete, G. (1983). A least-squares algorithm for fitting additive trees to proximity data. Psychometrika 48, 621-626.

Felsenstein, J. (1993). PHYLIP - Phylogenetic Inference Package, version 3.5.1. Distributed by the author. Department of Genome Sciences, University of Washington, Seattle, USA.

Frank, H., Rettenmeier, A., Weicker, H., Nicholson, G. J. \& Bayer, E. (1980). A new gas chromatographic method for determination of amino acid levels in human serum. Clin Chim Acta 105, 201-211.

Gordon, R. E., Barnett, D. A., Handerhan, J. E. \& Pang, C. H.-N. (1974). Nocardia coeliaca, Nocardia autotrophica, and the nocardin strain. Int J Syst Bacteriol 24, 54-63.

Groth, I., Schumann, P., Weiss, N., Martin, K. \& Rainey, F. A. (1996). Agrococcus jenensis gen. nov., sp. nov., a new genus of actinomycetes with diaminobutyric acid in the cell wall. Int J Syst Bacteriol 46, 234-239.

Huß, V. A. R., Festl, H. \& Schleifer, K. H. (1983). Studies on the spectrophotometric determination of DNA hybridization from renaturation rates. Syst Appl Microbiol 4, 184-192.

Jukes, T. H. \& Cantor, C. R. (1969). Evolution of protein molecules. In Mammalian Protein Metabolism, pp. 21-132. Edited by $\mathrm{H}$. N Munro. New York: Academic Press.

Lanyi, B. (1987). Classical and rapid identification methods for medically important bacteria. Methods Microbiol 19, 1-67.

MacKenzie, S. L. (1987). Gas chromatographic analysis of amino acids as the $N$-heptafluorobutyryl isobutyl esters. J Assoc Off Anal Chem 70, 151-160.

Marmur, J. (1961). A procedure for the isolation of deoxyribonucleic acid from microorganisms. J Mol Biol 3, 208-218.

Mesbah, M., Premachandran, U. \& Whitman, W. B. (1989). Precise measurement of the $\mathrm{G}+\mathrm{C}$ content of deoxyribonucleic acid by highperformance liquid chromatography. Int J Syst Bacteriol 39, 159-167.

Minnikin, D. E., Alshamaony, L. \& Goodfellow, M. (1975). Differentiation of Mycobacterium, Nocardia, and related taxa by thin-layer chromatographic analysis of whole-organism methanolysates. J Gen Microbiol 88, 200-204.

Minnikin, D. E., Collins, M. D. \& Goodfellow, M. (1979). Fatty acid and polar lipid composition in the classification of Cellulomonas, Oerskovia and related taxa. J Appl Bacteriol 47, 87-95. 
Prauser, H. \& Falta, R. (1968). Phagensensibilität, ZellwandZusammensetzung und Taxonomie von Actinomyceten. $Z$ Allg Mikrobiol 8, 39-46 (in German).

Rivas, R., Sánchez, M., Trujillo, M. E., Zurdo-Piñeiro, J. L., Mateos, P. F., Martínez-Molina, E. \& Velázquez, E. (2003). Xylanimonas cellulosilytica gen. nov., sp. nov., a xylanolytic bacterium isolated from a decayed tree (Ulmus nigra). Int J Syst Evol Microbiol 53, 99-103.

Rivas, R., Trujillo, M. E., Schumann, P., Kroppenstedt, R. M., Sánchez, M., Mateos, P. F., Martínez-Molina, E. \& Velázquez, E. (2004). Xylanibacterium ulmi gen. nov., sp. nov., a novel xylanolytic member of the family Promicromonosporaceae. Int $J$ Syst Evol Microbiol 54, 557-561.

Saddler, G. S., Tavecchia, P., Lociuro, S., Zanol, M., Colombo, L. \& Selva, E. (1991). Analysis of madurose and other actinomycete whole cell sugars by gas chromatography. J Microbiol Methods 14, 185-191.

Schleifer, K. H. (1985). Analysis of the chemical composition and primary structure of murein. Methods Microbiol 18, 123-156.

Schleifer, K. H. \& Kandler, O. (1972). Peptidoglycan types of bacterial cell walls and their taxonomic implications. Bacteriol Rev 36, 407-477.
Smibert, R. M. \& Krieg, N. R. (1994). Phenotypic characterization. In Methods for General and Molecular Bacteriology, pp. 611-651. Edited by P. Gerhart, R. G. E. Murray, W. A. Wood \& N. R. Krieg. Washington, DC: American Society for Microbiology.

Stackebrandt, E. \& Schumann, P. (2004). Reclassification of Promicromonospora pachnodae Cazemier et al. 2004 as Xylanimicrobium pachnodae gen. nov., comb. nov. Int J Syst Evol Microbiol 54, 1383-1386.

Stackebrandt, E., Schumann, P. \& Cui, X.-L. (2004). Reclassification of Cellulosimicrobium variabile Bakalidou et al. 2002 as Isoptericola variabilis gen. nov., comb. nov. Int J Syst Evol Microbiol 54, 685-688.

Uchida, K., Kudo, T., Suzuki, K. \& Nakase, T. (1999). A new rapid method of glycolate test by diethyl ether extraction, which is applicable to a small amount of bacterial cells of less than one milligram. J Gen Appl Microbiol 45, 49-56.

Yokota, A., Takeuchi, M., Sakane, T. \& Weiss, N. (1993). Proposal of six new species of the genus Aureobacterium and transfer of Flavobacterium esteraromaticum Omelianski to the genus Aureobacterium as Aureobacterium esteraromaticum comb. nov. Int J Syst Bacteriol 43, 555-564. 